\title{
Genetic and environmental dynamics to drug addiction
}

\author{
Maheen Waqar, Uzma Badar, Erum Shoeb.
}

Department of Genetics, University of Karachi, Pakistan.

Correspondence: email: maheenwaqarfarooq@gmail.com

\begin{abstract}
Drug addiction, relating to both licit and illicit substances, can be defined as an enduring disorder with certain chances of reversion categorised as uncontrollable drug consumption or the obsessive seeking and taking of drugs despite adverse consequences. It is a multifaceted complicated disorder with many inter-related causes, as well as neurobiological, environmental and genetic features. Genetic mutations and polymorphisms can be considered as reasons for instabilities in human regulatory systems like brain functioning, which lead to drug addiction. Environmental stimuli such as anxiety, stress and depression also play a crucial role in a person's addictive behaviours. Therefore, addiction to drugs is caused by neuro-adaptive changes and genetic-environment interactional modifications.
\end{abstract}

Keywords: drug addiction, neurobiology; genetics, environment, behavioural disorder

\section{Introduction}

Addiction is a complex disease that is multi-factorial and polygenic. In humans, drug addiction is a change over time from occasional drug taking to more compulsive drug taking, and a loss of control over the amount of drugs taken. ${ }^{1}$ Drug addiction, defined as the loss of control over drug use, or the compulsive seeking and taking of drugs despite adverse consequences, has become one of the most serious problems in the world. ${ }^{2}$ Addiction to drugs is a chronic, relapsing brain disease that if left untreated can cause major medical, social and economic problems. ${ }^{3}$ Substances that cause addiction are said to induce pleasing states (euphoria) or relieve distress. Constant consumption of such addictive substances induces adaptive deviations in the central nervous system that result in sensitisation, tolerance, physical dependence, desire, and reversion. ${ }^{4}$

Substance dependence or drug addiction involves motivational systems of the brain. Drug addiction may results from recurring drug intoxication and is modulated by both genetic and environmental factors. ${ }^{5}$ At different stages the influence of environment or genes are different. ${ }^{6,7}$ People who carry genetic susceptibility to substance dependence can have much greater impact of psycho-active materials on them, when exposed, than on someone who does not. ${ }^{8}$ There is also a genetic contribution to use of, and to the dependence on, a combination of alcohol, 
tobacco and other substances. ${ }^{9-15}$ Initiation of alcohol and tobacco use in adolescents is mostly influenced by environmental features. On the other hand genetic risk factors are of a much bigger involvement to habitual alcohol and tobacco usage in young adults. ${ }^{16}$

It has been estimated that genetic factors contribute to $40 \%-60 \%$ of the vulnerability to drug addiction, and environmental factors provide the balance. ${ }^{17}$ More than $30 \%$ of people once exposed to drugs become permanent drug addicts. ${ }^{3}$ Aside from the many social, economic and cultural factors that cause drug addiction, one of its key contributory factors is the genetic pre-disposition which makes people susceptible to drug addiction. ${ }^{8.18}$

The current review highlights the neurobiological changes behind drug addiction and possible genetic and non-genetic factors consequential to drug addiction.

\section{Neurobiology of drug addiction}

Neuroscientific approaches to drug addiction traditionally have been based on the premise that addiction is a process that results from brain changes (that may be genetic) which in turn results from chronic administration of drugs of abuse and addiction ${ }^{1}$. From the basic neuroscience perspective, the study of the neurobiology of drug addiction offers a novel opportunity to establish the biological basis of a complex and clinically relevant behavioural abnormality. ${ }^{19}$ Exposure to a drug results in cellular, molecular or epigenetic neuro-adaptations in interconnected brain circuits which, in susceptible individuals, are believed to underlie the transition to, and maintenance of, an addicted state. Furthermore, these adaptations alter the gene expression and ultimately affect the transcription and translation processes of the DNA and RNA. ${ }^{20}$

A drug enters the brain upon early exposure and binds itself to a specific protein target. This binding disturbs different functional operations of the nervous system, which in turn causes highly prominent behavioural effects. ${ }^{21}$ These changes in brain chemistry and function become significant and permanent due to continuous use of drugs resulting in drug dependence. Effective treatment is available for patients with nicotine, alcohol, and opiate addiction but successful treatment for stimulant or marijuana addiction is still not available. ${ }^{22}$

\section{Genetic factors}

Many researchers have reported that genetic factors, along with social and psychological factors, contribute to addiction. Alterations in different genes or gene expression that could be due to genetic mutations or genetic polymorphisms may be responsible for different addictive behaviours in different individuals; especially in the case of alcoholism. Genetic variability and genetic factors that influence the metabolism may increase the risk of addictive behaviours in an 
individual. ${ }^{20,23}$ Numerous genetic variants causing drug induction and stress can contribute further, leading to helplessness and the maximising of addiction. Drugs of abuse may alter the gene expression, consequently having an impact on protein expression as well.

An SNP (Single-Nucleotide Polymorphism) in the fatty acid amide hydrolase (FAAH) gene, encoding an endocannabinoid-inactivating enzyme has been found to be associated with the increased possibility of first time use of illegal drugs and alcohol. The majority of such recreational users later become permanent drug addicts. ${ }^{24}$

Studies have revealed the connection of addictive disease with genes, displaying the role of genes in increasing a person's susceptibility to addictive disease, with estimates of heritability of $30-60 \% .25$ Drug addiction is a relatively stable condition often resulting in gene expression changes ${ }^{1}$.Variation in gene expression as well as in the expression of protein products, in protein-protein interactions, in neural networks and in neurogenesis and synaptogenesis, influences brain activity and ultimately alters a person's behavior. ${ }^{25}$

Research reveals that techniques like molecular re-sequencing and Quantitative Trait Loci (QTLs) through Amplified Fragment Length Polymorphism (AFLP) or Single-Nucleotide Polymorphism (SNP) allow the investigations of molecular markers that are associated with the increased risk of addiction. ${ }^{26}$

\section{Environmental factors}

A person's environment can contribute to their tendency towards addiction. The tendency of a person's vulnerability towards drug addiction is not only genetically influenced but, also strongly influenced by his or her environment. Psychoanalysts and clinical psychologists emphasise more on the individual physiognomies of the drug addict and contemplate how factors such as stress, anxiety and depression, influence the development and maintenance of drug abuse and addiction or the desire of a person to take drugs and become an addict. ${ }^{1}$ Social risk factors are more difficult to isolate in research studies than specific neurobiological genes, but definitive patterns have emerged within environmental categories. Spiralling distress describes how, in some cases, the first self-regulation failure can lead to emotional distress, which sets up a cycle of repeated failures to self-regulate, and where each violation brings additional negative effects. ${ }^{27}$ It is often assumed that the emotion-altering effects of drugs are the major reasons for their use and more specifically that drugs are used to compensate for undesired emotional states produced by various events and environments. Environmental factors in adults, both intrinsic and extrinsic are also important determinants of self-administration behaviour, particularly during acquisition of the behaviour and during reinstatement of drug-taking following extinction. ${ }^{28}$ 
Stressful incidents in the environment during crucial periods of growth produce long-term neuro-endocrinological and developmental changes in the brain that influence drug related responses and tendencies to drug addiction. ${ }^{29}$

\section{Discussion}

The World Health Organisation ${ }^{30}$ and the American Psychiatric Association ${ }^{31}$ use the term 'substance dependence' rather than 'drug addiction' Substance dependence, often known as drug addiction, is a user's compulsive need to use drugs in order to function normally. When such substances are un-obtainable, the user suffers from withdrawal symptoms. ${ }^{32}$

Drug addiction is most often defined as a chronic relapsing disorder characterised by cycles of drug abuse, abstinence and repeated attempts to give it up. In drug addiction, obsessive drug-seeking and drug-taking behaviour persists despite serious negative consequences. ${ }^{4}$ The vulnerability for relapse is poorly understood but clearly involves multiple factors such as drug availability, conditioning factors and stress, and hypothetically can be driven by a residual 'brain signature'.$^{33}$ It can be characterised as a compulsion to take the drug with a narrowing of the behavioural repertoire toward excessive drug intake, and a loss of control in limiting intake. . $^{34,35}$

A process called 'maturing out' is when people using drugs in excess at an early age stop it when as they grow older. ${ }^{36}$ Following the persistent use of drugs, selfimposed withdrawal has also been observed in many individuals which may result in withdrawal symptoms in some cases, eventually causing the person to suffer from high levels of stress, anxiety and depression. ${ }^{37}$ Evidence from human studies suggests that the resistance to ceasing drug-seeking and taking behaviours during self-denial may aid in the avoidance of a relapse. ${ }^{38}$

Drug addiction and abuse is a major socio-economic problem related with substantial mortality and indisposition. In 2009, approximately 271 million people globally admitted to drug use at least once, representing closely to one in 20 people between 15-64 years of age. ${ }^{39}$ Drug dependence is set to take an immense toll in terms of economic loss and human misery. Studies reveal that genetic differences and specific social and environmental conditions can play a vital role in the development of drug manipulation. ${ }^{1}$ Psychologists regard drug addiction as a behavioural disorder which affects the victim by assuming control over a significant portion of an individual's interactive capabilities. ${ }^{40}$ It has been suggested that these drug-induced brain variations are not necessarily the crucial constituents of drug addiction; as the brain is adequately multifaceted and many of its activities can be modified. It is also said that the search for correlations to addiction is still necessarily an enduring one. ${ }^{1}$ 


\section{References}

1. Gail W, James HW, Chad MG, Tammy WG. Behavioural perspectives on the neuroscience of drug addiction. J Exp Anal Behav 2005; 84(3):667-81.

Doi: http://dx.doi.org/10.1901/jeab.2005.101-04

PMCid:PMC1389786

2. Nestler EJ. Molecular basis of long-term plasticity underlying addiction. Nat Rev Neurosci 2001;2: 119-28.

Doi: http://dx.doi.org/10.1038/35053570

PMid:11252991

3. Kreek MJ. Gene diversity in the endorphin system: SNPs, chips, and possible implications. In: Yudell M, DaSalle R (eds). The Genomic Revolution: Unveiling the Unity of Life. Joseph Henry Press: Washington DC 2002;97-108.

4. Jordi C and Magi F. Drug Addiction. N Engl J Med 2003;349:975-86.

Doi: http://dx.doi.org/10.1056/NEJMra023160

PMid:12954747

5. Rita ZG, Nora DV. Drug Addiction and Its Underlying Neurobiological Basis: Neuroimaging Evidence for the Involvement of the Frontal Cortex. Am. J. Psychiatry 2002;159(10):1642-52.

Doi: http://dx.doi.org/10.1176/appi.ajp.159.10.1642

6. Tsuang MT, Lyons MJ, Meyer JM, Doyle T, Eisen SA, Goldberg J, True W, Lin N, Toomey R, \& Eaves L. Co-occurrence of abuse of different drugs in men: the role of drug-specific and shared vulnerabilities. Arch. Gen. Psychiatry 1998;55:967-72.

Doi: http://dx.doi.org/10.1001/archpsyc.55.11.967

PMid:9819064

7. Tsuang MT, Lyons MJ, Harley RM, Xian H, Eisen S, Goldberg J, True WR and Faraone SV. Genetic \& environmental influences on transitions in drug use. Behav. Genet. 1999;29:473-79.

Doi: http://dx.doi.org/10.1023/A:1021635223370

PMid:10857252 
8. WHO. Neuroscience of psychoactive substance use and dependence 2004. ISBN 924159124 2(NLM classification: WM 270). http://www.who.int/substance_abuse/publications/en/Neuroscience_E. pdf

9. Carmelli D et al. Genetic influence on smoking: a study of male twins. New England Journal of Medicine 1992;327:829-33.

Doi: http://dx.doi.org/10.1056/NEJM199209173271201

PMid:1508241

10. Reed $\mathrm{T}$ et al. Correlations of alcohol consumption with related covariates and heritability estimates in older adult males over a 14- to 18-year period: the NHLBI Twin Study. Alcoholism: Clinical and Experimental Research 1994;18:702-10.

Doi: http://dx.doi.org/10.1111/j.1530-0277.1994.tb00934.x

PMid:7943679

11. Swan GE, Carmelli D, Cardon LR. The consumption of tobacco, alcohol, and coffee in Caucasian male twins: a multivariate genetic analysis. Journal of Substance Abuse 1996;8:19-31.

Doi: http://dx.doi.org/10.1016/S0899-3289(96)90055-3

12. Swan GE, Carmelli D, Cardon LR. Heavy consumption of cigarettes, alcohol and coffee in male twins. Journal of Studies on Alcohol 1997;58:182-90.

\section{PMid:9065896}

13. Daeppen JB et al. Clinical correlates of cigarette smoking and nicotine dependence in alcohol-dependent men and women: the Collaborative Study Group on the Genetics of Alcoholism. Alcohol and Alcoholism 2000;35:171-75.

Doi: http://dx.doi.org/10.1093/alcalc/35.2.171

PMid:10787393

14. Hopfer CJ, Stallings MC, Hewitt JK. Common genetic and environmental vulnerability for alcohol and tobacco use in a volunteer sample of older female twins. Journal of Studies on Alcohol 2001;62:717-23.

PMid:11838905 
15. Tsuang MT et al. The Harvard Twin Study of Substance Abuse: what we have learned. Harvard Review of Psychiatry 2001;9:267-79.

PMid:11600486

16. Koopmans JR, van Doornen LJ, Boomsma DI. Association between alcohol use and smoking in adolescent and young adult twins: a bivariate genetic analysis. Alcoholism: Clinical and Experimental Research 1997;21:537-46.

PMid:9161615

17. Uhl GR. Molecular genetic underpinnings of human substance abuse vulnerability: likely contributions to understanding addiction as a mnemonic process. Neuropharmacology 2004;47(1):140-47.

Doi: http://dx.doi.org/10.1016/j.neuropharm.2004.07.029

PMid:15464133

18. Nielsen DA, Ji F, Yuferov V, Ho A, Chen A, Levran O, Ott J and Kreek MJ. Genotype patterns that contribute to increased risk for or protection from developing heroin addiction. Nature, Molecular Psychiatry 2008;13:417-28.

Doi: http://dx.doi.org/10.1038/sj.mp.4002147

PMid:18195715 PMCid:PMC3810149

19. Eric JN. Molecular Mechanisms of drug addiction. The Journal of Neuroscience 1992;12(7):2439-50.

20. Jhodie RD. Current Perspectives on the Neurobiology of Drug Addiction: A Focus on Genetics and Factors Regulating Gene Expression. ISRN Neurology 2012;2012:24.

21. Eric JN. Molecular Neurobiology of Addiction. The American Journal on Addictions 2001;10:201-217.

Doi: http://dx.doi.org/10.1080/105504901750532094

22. Thomas AM, David CL, Charles POB, Herbert DK. Drug Dependence, a Chronic Medical Illness Implications for Treatment, Insurance, and Outcomes Evaluation. JAMA 2000; 284(13):1689-1695.

http://dx.doi.org/10.1001/jama.284.13.1689 
23. Crabbe JC. Genetic contributions to addiction. Annu Rev Psychol 2002;53:435-62.

Doi: http://dx.doi.org/10.1146/annurev.psych.53.100901.135142

PMid:11752492

24. Sipe JC, Chiang K, Gerber AL, Beutler E, Cravatt BF. A missense mutation in human fatty acid amide hydrolase associated with problem drug use. ProcNatlAcadSci U S A 2002;99:8394-99.

Doi: http://dx.doi.org/10.1073/pnas.082235799

PMid:12060782 PMCid:PMC123078

25. Behnam Z, Ali G, Hamed E. Genetic influences on drug abuse and addiction; interactions of endophenotypes and genotypes. Basic and Clinical Neuroscience 2010;1:3.

26. Uhl GR, Liu QR, Naiman D. Substance abuse vulnerability loci: Converging genome scanning data. Trends Genet 2002;18:420-25.

Doi: http://dx.doi.org/10.1016/S0168-9525(02)02719-1

27. Baumeister RF, Heatherton TF, Tice DM. Losing Control: How and Why People Fail at Self-Regulation. San Diego, Academic Press 1994.

28. Le Sage MG, Stafford D, Glowa JR. Preclinical research on cocaine self-administration: Environmental determinants and their interaction with pharmacological treatment. NeurosciBiobehav Rev. 1999;23:71741.

Doi: http://dx.doi.org/10.1016/S0149-7634(99)00015-9

29. Henry C, Kabbaj M, Simon H, Le Moal M, Maccari S. Prenatal stress increases the hypothalamo-pituitaryadrenal axis response in young and adult rats. J Neuroendocrinol. 1994;6:341-45.

Doi: http://dx.doi.org/10.1111/j.1365-2826.1994.tb00591.x

PMid:7920600

30. World Health Organization. The ICD-10 classification of mental and behavioural disorders: clinical descriptions and diagnostic guidelines. Geneva: World Health Organization 1992. 
31. American Psychiatric Association. Diagnostic and statistical manual of mental disorders, 4th ed., text revision: DSM-IV-TR. Washington, D.C.: American Psychiatric Association 2000.

32. National Institutes of Health website: "Drug dependence means that a person needs a drug to function normally. Abruptly stopping the drug leads to withdrawal symptoms. Drug addiction is the compulsive use of a substance, despite its negative or dangerous effects. http://www.ncbi.nlm.nih.gov/pubmedhealth/PMH0002490/.

33. George FK, Michel LM. Drug Addiction, Dysregulation of Reward and Allostasis. Neuropsychopharmacology 2001;24:97-129.

Doi: http://dx.doi.org/10.1016/S0893-133X(00)00195-0

34. American Psychiatric Association. Diagnostic and Statistical Manual of Mental Disorders, 4th ed. Washington DC, American Psychiatric Press 1994.

35. World Health Organization. International Statistical Classification of Diseases and Related Problems, 10th ed. Geneva, World Health Organization 1992.

36. Chen K, Kandel DB. The natural history of drug use from adolescence to the mid-thirties in a general population sample. American Journal of Public Health 1995;85:41-7.

Doi: http://dx.doi.org/10.2105/AJPH.85.1.41

37. McKeon A, Frye MA, Delanty N. The alcohol withdrawal syndrome. Journal of Neurology, Neurosurgery and Psychiatry 2008;79(8):85462.

Doi: http://dx.doi.org/10.1136/jnnp.2007.128322

PMid:17986499 
38. Economidou D, Pelloux Y, Robbins TW, Dalley JW, Everitt BJ. High impulsivity predicts relapse to cocaine-seeking after punishmentinduced abstinence. Biological Psychiatry 2009;65:851-56.

Doi: http://dx.doi.org/10.1016/j.biopsych.2008.12.008

PMid:19181308

39. Degenhardt L, Hall W. Extent of illicit drug use and dependence, and their contribution to the global burden of disease. Lancet 2012;379(9810):55-70.

Doi: http://dx.doi.org/10.1016/S0140-6736(11)61138-0

40. Higgins ST, Heil SH, Lussier JP. Clinical implications of reinforcement as a determinant of substance use disorders. Annual Review of Psychology 2004;55:431-61.

Doi: http://dx.doi.org/10.1146/annurev.psych.55.090902.142033

PMid:14744222 